UNITED NATIONS CONFERENCE ON TRADE AND DEVELOPMENT

INTELLECTUAL PROPERTY: HOW MUCH ROOM IS LEFT FOR INDUSTRIAL POLICY?

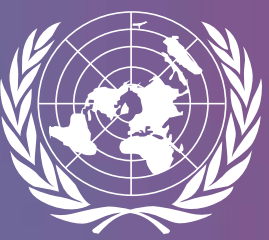

UNITED NATIONS 



\title{
INTELLECTUAL PROPERTY: HOW MUCH ROOM IS LEFT FOR INDUSTRIAL POLICY?
}

\author{
Carlos M. Correa
}

No. 223

October 2015

Acknowledgments: This paper was written as a background paper for UNCTAD's Trade and Development Report, 2014. The author thanks Richard Kozul-Wright for his helpful comments and the Social Sciences and Humanities Research Council of Canada and the Trudeau Foundation for their support. 
The opinions expressed in this paper are those of the author and are not to be taken as the official views of the UNCTAD secretariat or its member States. The designations and terminology employed are also those of the author.

UNCTAD Discussion Papers are read anonymously by at least one referee, whose comments are taken into account before publication.

Comments on this paper are invited and may be addressed to the author, c/o the Publications Assistant, Macroeconomic and Development Policies Branch, Division on Globalization and Development Strategies, United Nations Conference on Trade and Development, Palais des Nations, CH-1211 Geneva 10, Switzerland; e-mail: gdsinfo@unctad.org.

UNCTAD Discussion Papers are available on the UNCTAD website at http://unctad.org. 


\section{Contents}

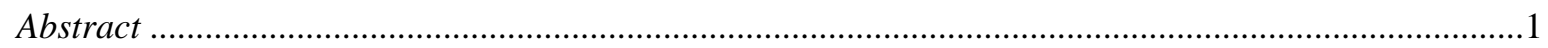

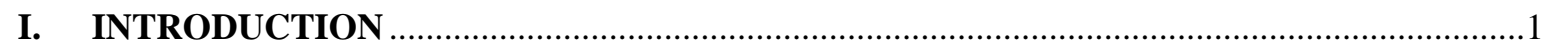

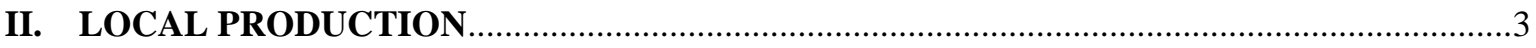

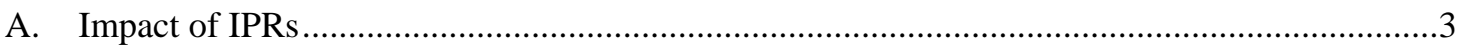

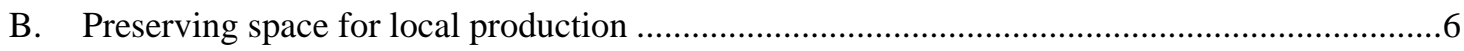

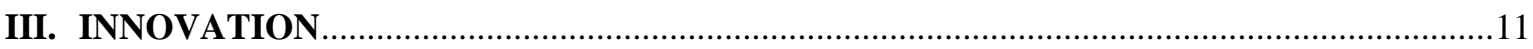

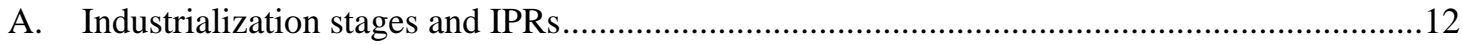

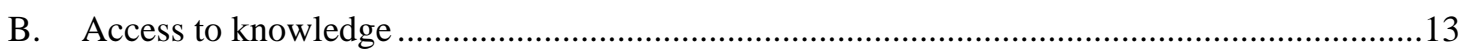

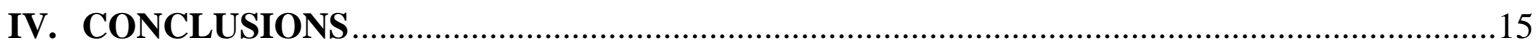

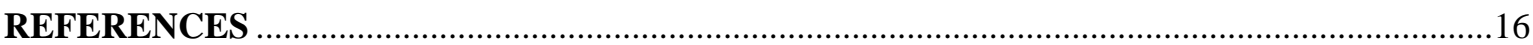

\section{List of tables}

1 Intellectual property rights in manufacturing activities..................................................................4

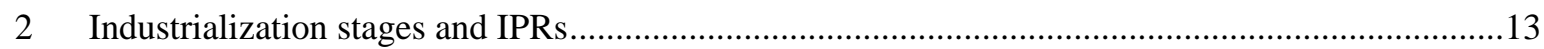





\title{
INTELLECTUAL PROPERTY: HOW MUCH ROOM IS LEFT FOR INDUSTRIAL POLICY?
}

\author{
Carlos M. Correa \\ University of Buenos Aires/South Centre
}

\begin{abstract}
The early industrialization process in developed countries took place under flexible frameworks of intellectual property protection. Those countries, however, proposed and obtained in trade negotiations the adoption of an international intellectual property regime that expanded and strengthened such protection. While the role of this regime, especially patents, in promoting innovation is controversial, it may effectively limit the ability of developing countries to implement industrial policies. These countries can preserve some room to implement such policies by using certain flexibilities, such as applying rigorous standards of patentability and granting compulsory licenses to broaden the space for local production.
\end{abstract}

\section{INTRODUCTION}

Developing countries have largely focused on and carefully assessed during multilateral trade negotiations that took place in the last 30 years, the possible impact of measures relating to agriculture. For both net agricultural exporter and importer countries this has been a crucial issue, particularly as multilateral rules may affect food security. Developing countries have also been conscious that tariff reductions for manufacturing products (as demanded in tariff negotiations on non-agricultural goods) could be detrimental to local industries and unemployment. Substantial tariff reductions would deprive them of one of the main instruments available to implement industrial policies. Countries that already have an industrial base may not be able to cope with foreign competition while those aiming at creating such base might be never able to do so.

However, the extent to which the disciplines that the World Trade Organization (WTO) adopted on intellectual property rights (IPRs) could affect the design and implementation of industrial policies only received marginal attention during the negotiations under the General Agreement on Tariff and Trade (GATT). One difficulty is that assessing the possible impact of such rules is complex, as quantitative models cannot be easily developed and applied. The acceptance by developing countries of the Trade-Related Aspects of Intellectual Property Rights (TRIPS) Agreement as part of the outcomes of the Uruguay Round was not based on any evidence about the benefits that it could bring about to their economies. Rather, the Agreement was accepted in exchange for concessions in agriculture and textiles - the "grand deal" of the Uruguay Round. Despite some attempts to limit the scope of a future agreement and the level of protection to be granted, developed countries largely imposed their own standards of IPRs protection.

A vast literature has examined how the now advanced countries framed their IPRs regimes while they were in the process of expanding their industrial base. Historical studies show that the early industrialization process in those countries took place under flexible frameworks of IPRs protection (e.g. Commission on Intellectual Property Rights, 2002). Significantly, the design of such frameworks 
deliberately took into account the need to get access to foreign technologies and to promote the local dissemination of innovations. As the industrialization process advanced, various industry groups were able to induce the adoption of increasingly high standards of intellectual property protection.

The choice of a flexible IPRs system and, in particular, discrimination against foreigners, was not an accidental feature in the legislation of developed countries at earlier stages of their industrial development. Thus, the United States Congress' Office of Technology Assessment (1986: 228) noted that "[W]hen the United States was still a relatively young and developing country, for example, it refused to respect international intellectual property rights on the grounds that it was freely entitled to foreign works to further its social and economic development". An egregious example of this policy can be found in the area of copyright, where the United States refused to grant copyright protection to foreign authors until the end of the XIX Century, despite the complaints and efforts of frustrated British authors. The objective of this policy was to expand literacy with cheap yet excellent books and give United States publishers and their employees the needed de facto advantage afforded by the absence of protection (e.g. Vaidhyanathan, 2001). It was considered that granting copyright to foreigners would give them a monopoly at the expense of United States reading public (Vaidhyanathan, 2001). Similarly, foreign investors were discriminated under the patent law through various limitations in order to facilitate imitation based on foreign technologies. ${ }^{1}$

Some European countries equally resisted the introduction of IPRs protection that could undermine their industrial development. Thus, despite pressures from the more technologically advanced Germany, Switzerland opted for a limited protection in line with the views expressed by its industries ${ }^{2}$ and, in particular, denied patent protection to chemical products in order to avoid an increase in imports and the loss of local industrial capacity. ${ }^{3}$

The room for manoeuvre enjoyed by developed countries is not any longer available under the TRIPS Agreement. One important question is, hence, the extent to which the IRPs standards constrain developing countries' ability to implement industrial policies aiming at expanding local production and value added.

This paper examines aspects of IPRs legislation that may affect the implementation of industrial policies aiming at promoting local production and innovation, and how the use of some of the "flexibilities" contained in the TRIPS Agreement, as extensively examined in academic analyses (e.g. Reichman, 1996-1997; Musungu and Oh, 2005; Correa, 2007a) and authoritative reports (e.g. Commission on Intellectual Property Rights, 2002; WHO, 2006; UNAIDS et al., 2011), may mitigate the effects of the commitments made under the TRIPS Agreement. ${ }^{4}$

\footnotetext{
1 "Between 1790 and 1836, as a net importer of technology, the US restricted the issue of patents to its own citizens and residents. Even in 1836, patents fees for foreigners were fixed at ten times the rate for US citizens (and two thirds as much again if one was British!). Only in 1861 were foreigners treated on an (almost wholly) non-discriminatory basis” (Commission on Intellectual Property Rights, 2002: 20).

${ }^{2}$ A survey published by the Zurich Chamber of Commerce in 1886 stated: "The majority of the big industrialists of Zurich are not in favor of the granting of patents. They do not wish to give up the freedom to make use of the improvements of foreign competitors as they see fit. Many see in the present situation the last advantage, which remains, to them in foreign competition and they do not wish to see it wrenched from their hand. This is held to be the case-as we especially set out-not only with respect to imitation but also particularly with respect to the free development of the play of forces" (as quoted in Ritter, 2004: 484).

${ }^{3}$ Swiss Federal Councillor Brenner stated during the Parliament's debates about patent law: "In our deliberations on this law, we would do well to bear in mind that it should be framed in such a way that it is adapted to the needs of our own industries and conditions in our own country. These considerations, rather than the demands and claims of foreign industries, must be our primary concern in shaping the law" (Gerster, 2001: 10).

${ }^{4}$ It is worth noting that Least Developed Countries (LDCs) are exempted from implementing TRIPS obligations until 1 July 2021 - or when a particular country ceases to be in the least developed category if that happens before that date.
} 


\section{LOCAL PRODUCTION}

\section{A. Impact of IPRs}

IPRs cover a wide range of matters including inventions, signs used as trademarks, geographical indications, secret know-how, creative works and artistic performances, functional and ornamental designs, plant varieties, integrated circuits' designs and test data for medicines and agrochemicals. The TRIPS Agreement requires WTO members to respect minimum standards in most of these areas.

IPRs confer, in general, exclusive rights. This means that third parties cannot exploit the protected subject matter without the authorization of the right-holder. Such exclusive rights notably encompass the right to manufacture and sell in the country where protection is granted. In the case of product patents, the protection conferred means that nobody can produce and sell the covered product without infringing the patent, unless a voluntary or compulsory license is granted. If a manufacturing process is protected, it cannot be executed in the country of protection; moreover the importation of a product that is directly obtained through the use of patented process in a foreign country may be prevented by the patent-holder. ${ }^{5}$

Local production in developing countries often depends on the access to foreign technologies, except in technologically mature sectors where technical know-how is readily available or where domestic innovation has taken place. This means that IPRs, particularly patents - overwhelmingly owned by developed countries' companies ${ }^{6}$ - may determine the extent to which local production can be undertaken or not. If voluntary licenses are not granted, or the government does not allow use of the protected technologies under compulsory licenses, ${ }^{7}$ local companies face the risk of litigation and exclusion from the market. ${ }^{8}$

Examples of limitations to local production derived from IPRs can be found in various fields. For instance, six countries - France, Germany, Japan, the Republic of Korea, the United Kingdom and the United States - were the source of almost 80 per cent of all patented innovations in several fields of environmentally sound technologies (see UNEP et al., 2010). Chinese firms struggled to obtain competitive technologies to locally produce wind turbines and were only able to get licenses and know-how from second-tier firms (Khor, 2012). Even in the absence of patents, local production may be limited by constraints relating to secret know-how, an important area of IPRs protection that has attracted growing interest in recent times. ${ }^{9}$

Pharmaceuticals provide another outstanding example. Innovation-based pharmaceutical companies hold large patent portfolios to control production and marketing of their drugs worldwide. In order to delay competition, those companies generally apply and (often obtain) a large number of

\footnotetext{
${ }^{5}$ This is the effect of the extension of protection of process patents mandated by Article 28.1(b) of the TRIPS Agreement.

${ }^{6}$ China and Indonesia are possibly the only developing countries where the number of domestic patent applications is greater than foreigners' (see WIPO Statistical Country profiles, available at http://www.wipo.int/ipstats/en/statistics/country_profile/). In the case of Indonesia, this is explained by the large number of patents applied for by (but not necessarily exploited) by scientists working in universities and government research institutions in order to obtain credits for job promotion and increased salary (see Rochmyaningsih, 2013).

${ }^{7}$ These licenses have only been exceptionally granted in developing countries, as discussed below.

${ }^{8}$ In many cases, such exclusion is mandated by court's provisional injunctions, before a determination whether infringement actually existed is made. On the abuse of provisional measures in IPRs cases, see Correa (2000).

${ }^{9}$ According to the Executive Office of the President of the United States (2013: 1-2): "We will continue to act vigorously to combat the theft of U.S. trade secrets that could be used by foreign companies or foreign governments to gain an unfair economic edge”. Sinoval, China's biggest wind turbine manufacturer, was sued by AMSC, a previous supplier, on grounds of breach of contract, copyright infringement and misappropriation of trade secrets. About US\$ 1.2 billion in damages were claimed.
} 
"evergreening” patents on minor or trivial developments (Correa, 2011) ${ }^{10}$ that may be used to delay generic competition, in both developed and developing countries. ${ }^{11}$ Notably, after the TRIPS Agreement entered into force in India local firms with manufacturing capacity needed to concentrate on off-patent products; in only one case, a local firm was able to obtain a compulsory license from the government. As a result, the ability of India to remain as a supplier of low-cost medicines and keep the role of "the pharmacy of developing countries" is at risk. ${ }^{12}$ While there is some degree of licensing in pharmaceuticals, innovation-based pharmaceutical companies are generally reluctant to loss control over their products, particularly the most profitable ones. In addition, licensing agreements often limit local production to the formulation of medicines while active ingredients are provided by the licensor.

Table 1, which summarizes how different types of IPRs may affect various manufacturing sectors, suggests that patents, trade secrets, industrial designs and utility models are likely to be the most relevant modalities of IPRs in relation to industrialization policies.

Table 1

Intellectual property rights in manufacturing activities

\begin{tabular}{ll}
\hline Types of intellectual property right & \multicolumn{1}{c}{ Main fields } \\
\hline Patents & $\begin{array}{l}\text { Chemicals, drugs, plastics, engines, turbines, electronics, } \\
\text { industrial control and scientific equipment } \\
\text { Mechanical industry }\end{array}$ \\
Utility models & Clothing, automobiles, electronics, furniture, etc. \\
Industrial designs & Chemistry, biotechnology, food and other processing industries \\
Trade secrets & Printing \\
Copyright & All industries \\
Trademarks & Microelectronics \\
Integrated circuits &
\end{tabular}

Source: Based on Correa (2010).

The number of patents applied for, even by foreigners, in countries with low levels of industrial development is generally low, ${ }^{13}$ since technology owners do not expect imitation and competition by local companies. ${ }^{14}$ As the level of industrial development and the risk of imitation increases, patenting by foreigners also moves up.

Utility models (sometimes called "petty patents") permit protection of innovations of an incremental nature, mainly in the mechanical field. They have been regarded as an instrument better adapted to developing countries in early stages of industrialization than patents, as the cost and time for acquiring them is shorter and they are generally granted without prior examination (see e.g. Suthersanen et al., 2007). A large number of utility models have been applied in Brazil and China, overwhelmingly by

\footnotetext{
${ }^{10}$ For instance, over 800 patents were filed to protect different aspects and methods of use of ritonavir, an HIV/SIDA drug included in the WHO list of essential medicines (see WIPO, 2011).

${ }^{11}$ Biotech/pharmaceuticals is the second sector in terms of the number of patent disputes litigated in courts in the United States. The number of cases more than tripled between 1995-2000 and 2007-2012. See Nurton J, "Five trends in patent litigation”, August 2013, available at: http://www.managingip.com/Blog/3238467/Five-trendsin-US-patent-litigation.html. Often companies holding patents pay their potential competitors to delay the entry of generic products into the market, a practice that can be deemed an antitrust violation in some jurisdictions. See Lim D, “Reverse Payments - Life After Actavis”, IIC (2014) 45:1-5.

${ }^{12}$ Indian generic firms provide around 80 per cent of drugs for HIV/AIDS consumed in developing countries.

${ }^{13}$ See WIPO IP Statistics at http://www.wipo.int/ipstats/en/.

${ }^{14}$ Patenting concentrates in those countries in the pharmaceutical field.
} 
domestic applicants. ${ }^{15}$ They have also been extensively used in Japan. There is no evidence, however, on the extent to which utility models actually promote innovation.

Industrial designs may also be functional to the development of some industries, as noted in table 1 . While the fact that they are granted without prior examination provides - as in the case of utility models - a great advantage for entering into the system, it also generates the risk of initiating infringement procedures that may end up with damages imposed on the title holder if the design is finally determined to be invalid.

Trade secrets protection is relevant for some industries, such as chemicals, particularly when the costs and time of overcoming the secrecy barrier by legitimate reverse engineering are substantial. One advantage of this form of protection is that its acquisition has no costs, and protection lasts as long as the secrecy is preserved. In exchange, it does not confer exclusive rights. However, the protection of know how may involve substantial economic interests (see e.g. Executive Office of the President of the United States, 2013).

Technical knowledge available in published literature, reports, etc. may provide inputs for local innovation. While the impact of copyright regimes is generally considered in the context of educational policies, they may have a broader impact, including in respect of learning processes associated to the creation of industrial capacities.

Trademark regimes are generally more neutral to industrial policies than other IPRs. The protection of integrated circuits may only be relevant in countries where semiconductor production takes place. In addition, this modality of protection has apparently been of little practical impact (see e.g. Hoeren, 2010).

Given the significant impact that patents may have in determining the use of technical knowledge and on the implementation of industrial policies aiming at expanding local production and value added, the analysis that follows focuses to a great extent on the relationship between patents and industrial policies. Patent law regimes need to be adequately integrated into such policies (Commission on Intellectual Property Rights, 2002).

As shown in table 1, patents may affect the most technologically dynamic sectors where domestic value added can be higher as compared to sectors where more mature technologies predominate. Hence, for countries willing to move ahead in their industrialization process it is crucial to explore how to design their patent regimes in a manner that expands the opportunities for access to and diffusion of technology. In early stages of industrial development, as shown by the history of patent protection, such regimes should limit - as far as compatible with the country's international obligations - the scope of patent protection and of other IPRs. This can be done, but to some extent only, by using what are known as the "flexibilities" allowed by the TRIPS Agreement discussed below.

One noticeable example of a patent policy explicitly designed to pursue industrial policy objectives was the amendment of the Japanese patent law in 1959, which subordinated "the short-term interests of the innovator in the creation of exclusionary rights to the broader policy goals of diffusion of technology" (Ordover, 1991: 48). Section 1 of the Japanese patent code stated that the objective of the patent law was "to encourage inventions by promoting their protection and utilization so as to contribute to the development of industry" (Girouard, 1996: 11; emphasis added). This objective was actively pursued through a number of mechanisms aimed at promoting the importation, absorption and

\footnotetext{
${ }^{15}$ In Australia, a special regime of "innovation patents" was instituted to protect technical developments that do not meet the inventive threshold required for standard patents. They last for 8 years and are granted (usually within a month of filing the complete application) without examination. For an analysis of the use of innovation patents, see Verve Economics (2013).
} 
diffusion of foreign technology until substantial amendments were introduced to the patent law in $1994 .^{16}$

Table 1 also suggests that the extent to which the lack of or the limited access to IPRs-protected technologies may constrain the industrialization processes will depend on the industrial profile of each country. Thus, IPRs can be neutral in that respect ${ }^{17}$ in countries at an incipient phase of industrialization where technologically mature technologies prevail (such as textiles, food processing, metal working) which may be acquired embedded in equipment or through engineering firms. As the manufacturing production of a country becomes more diversified and higher value added is sought (e.g. fine chemicals, electronic equipment and consumer goods) IPRs may growingly narrow down the freedom to operate in the absence of a license authorizing the use of the protected technologies and designs.

It should also be noted that the intensity of foreign patenting is generally related to the local imitative capabilities available in a country. In countries where such capabilities are limited patenting often concentrates in pharmaceuticals, where innovator companies are eager to exclude competition from generic drugs, whether imported or locally produced. ${ }^{18}$ Patenting is not significant instead in other areas where technology holders do not expect competition by local manufacturers, as they can enforce their IPRs in the countries that may produce and eventually export imitated products. For instance, a study found that only 1 per cent of patent applications relating to clean energy technologies (CET) have also been filed in Africa (UNEP and EPO, 2013: 13). This information has been interpreted as evidence "that claims ... that patent rights provide a barrier to use of CETs, are very largely unfounded for Africa" (UNEP and EPO, 2013: 13). This is true in terms of barriers to local production, which would not take place anyway due to lack of manufacturing capacity. However, patents granted and enforced in countries (e.g. China, India) where such capacity exists can create barriers for the export of low cost equipment and technologies to Africa, thereby limiting the prospects for advancing the industrialization process in the continent.

\section{B. Preserving space for local production}

There are several alternatives that countries have under the TRIPS Agreement to preserve or expand the space for local production, while respecting the minimum standards established by that agreement.

\section{(i) Patentability standards}

There is an inverse relationship between the scope of patent protection and the "freedom-to-operate" available to local firms. The broader the protection conferred, the higher the risk of being excluded from a particular market. There is, however, considerable room to define such scope at the national level.

First, countries are free to define bona fide ${ }^{19}$ when there is an "invention" that may be deemed patentable if the relevant patentability requirements (discussed below) are met. Thus, they may exclude from patentability biological materials found in nature (even if isolated therefrom) and make a clear distinction between "discovery" and "invention". An approach of this type may be important, for instance, to create space for the development of a local biotechnological industry based on reverse

\footnotetext{
${ }^{16}$ On the recent evolution of the patent regime in Japan, see Tamura, 2013.

${ }^{17}$ Other impacts may, nevertheless, be significant, for instance, in relation to access to drugs and inputs for agriculture.

18 The largest proportion of patents applied for and granted in many developing countries relate to pharmaceuticals.

${ }^{19}$ The bona fide interpretation of international treaties' rules is a recognized principle of international law (see Article 30 of the Vienna Convention on the Law of the Treaties).
} 
engineering of existing technologies that may otherwise be constrained by broad patent claims of foreign firms.

Second, patents may be conferred on the basis of a more or less rigorous concept of "inventive step". It has been often been argued that the application of rigorous patentability standards in developing countries would have negative effects, as it would prevent small and medium companies from applying for and obtaining patents that would not be viable if higher standards were applied. This argument assumes, on the one hand, that such companies may use the patent system in a manner comparable to large companies, while the evidence suggests that this is not the case for various reasons, including the cost of acquiring patents and, particularly, of litigation. ${ }^{20}$ On the other, foreign applicants are generally much better equipped than local companies to take advantage from lax patentability standards, as evidenced by the "evergreening" strategies followed by pharmaceutical companies in developing countries (see Correa, 2011). The argument also assumes that obtaining a patent and excluding others from the market is per se good policy, irrespective of whether the applicant has made some significant technical contribution or not. This ignores that competition, rather than market exclusion, can be a major driver of innovation. As noted by the Federal Trade Commission (2003: 1-2) of the United States:

Competition can stimulate innovation. Competition among firms can spur the invention of new or better products or more efficient processes. Firms may race to be the first to market an innovative technology. Companies may invent lower cost manufacturing processes, thereby increasing their profits and enhancing their ability to compete. Competition can prompt firms to identify consumers' unmet needs and develop new products or services to satisfy them.

A low inventive step requirement leads to the proliferation of patents - sometimes referred to as "low quality" patents. ${ }^{21}$ Such patents may be used to keep competitors out of the market, especially if they are unable or unwilling to litigate and eventually challenge the validity of wrongly granted patents.

In fact, from the perspective of an industrial policy aiming at expanding the freedom-to-operate of local firms, the rigorous application of the test of inventive step is what makes sense (Correa, 2011). The number of patents granted may thereby be limited and the space for competition preserved. Such a rigorous application would ensure that patents are granted only where there has been a genuine technical development, and avoid the use of patents on minor or trivial developments to deter competitors or subject them to costly litigation. ${ }^{22}$

Third, industrial applicability may be required - as many countries do - to grant a patent. While some countries require instead the prospect of a mere "utility", as it is the case in the United States, there is nothing in the TRIPS Agreement mandating this latter approach. Moreover, industrial applicability may be applied in such a manner as to limit patents to technical developments that lead to the generation of products, as opposed to inventions that may be just used in an industry. ${ }^{23}$ Case law in Canada also shows efforts to narrow down the concept of "usefulness". Courts have developed the socalled "promise doctrine" in accordance to which filing for patents should not be done too early, before the idea has a clear purpose and the promised usefulness of the invention cannot be soundly

\footnotetext{
${ }^{20}$ Bessen and Meurer (2008: 16; emphasis in original) have observed, that even in developed economies, "taking the effect of other owners' patents into account, including the risk of litigation, the average public firm outside the chemical and pharmaceutical industries would be better off if patents did not exist”.

${ }^{21}$ For the United States, see e.g., Jaffe and Lerner, 2004.

${ }^{22}$ In line with this reasoning, the World Bank (2001: 143) has recommended developing countries to "set high standards for the inventive step, thereby preventing routine discoveries from being patented".

${ }^{23}$ It is to be noted that the concept of "industry" generally applied under patent law is not limited to manufacturing. It encompasses inventions applicable in other fields, such as agriculture.
} 
predicted. The doctrine was applied, for instance, in a case where a Canadian pharmaceutical company, Apotex, wished to undertake local production of a drug patented by Eli Lilly. ${ }^{24}$

Fourth, patent claims should be limited to what the applicant has actually invented and they should be interpreted in a manner that does not unduly expand the scope of protection. Although this would seem to be quite straightforward suggestion for the proper functioning of a patent system, the practices of patent offices and courts have been oriented in many jurisdictions in an opposite direction. Thus, it has become common for chemical and pharmaceutical companies to claim substances defined with general formulae that may include millions of compounds for which no testing has been conducted. ${ }^{25}$

\section{(ii) Compulsory Licenses}

As a patent (as well as other IPRs) confer exclusive rights, the protected subject matter may not be manufactured and commercialized without the consent of the right-holder. If this consent is withheld, even if local manufacturing capacity exists, local production can be prevented. Compulsory licenses provide a possible solution to this problem. They are allowed under Article 31 of the TRIPS Agreement. Importantly, this provision does not limit the grounds for the grant of compulsory licenses, including non-commercial government use. Such licenses may be used both for local production as well as for importation of patented products.

The grant of a patent does not guarantee that an invention will be industrially exploited in the country of grant, not even that the protected product will be imported. Decisions about where to produce or to import/export are, in principle, left to right holders. However, patent rights are not absolute, but granted to attain public interest objectives, and not just the private benefit of right holders. ${ }^{26}$

The possibility of granting a compulsory license in the case of "lack of working" was recognized under the Paris Convention for the Protection of Industrial Property (hereinafter "the Paris Convention"), which considered the absence or insufficiency of exploitation as an "abuse". ${ }^{27}$ The "working obligation" reflected the paradigm predominant at that time regarding the role of patents: they were granted to promote transfer of technology and the development of industrial capacities in the country of grant, and not as a mere import monopoly. Lack of working was, thus, qualified as an “abuse” (Halewood, 1997).

During the Uruguay Round negotiations that ultimately led to the adoption, inter alia, of the TRIPS Agreement, developed countries attempted to explicitly exclude any working obligation, while

\footnotetext{
${ }^{24}$ The court's decision to revoke Eli Lilly's patent based on this doctrine, led the United States pharmaceutical company to initiate an investor-State dispute settlement proceeding (see http://insidetrade.com/inside-ustrade/eli-lilly-moves-forward-nafta-challenge-canadian-patent-dispute) (Correa, 2013).

${ }^{25}$ These are the so-called "Markush claims". A study revealed, for instance, that 86 per cent of patents registered in one year in South Africa (where no prior examination of patent applications exists yet) included that type of claims. Markush claims account for the largest portion of all patents issued in South Africa. In the case of Argentina, around 50 per cent of the patents granted in the 2000-2007 period were also based on Markushclaims. In India, at least 630 out of the 1432 product patents granted in the examined period contained Markush claims (see Correa, 2011).

${ }^{26}$ In a letter from Thomas Jefferson to Isaac McPherson, an inventor, of 13 August 1813, Jefferson stated: "Inventions then cannot, in nature, be a subject of property. Society may give an exclusive right to the profits arising from them, as an encouragement to men to pursue ideas which may produce utility, but this may or may not be done, according to the will and convenience of the society, without claim or complaint from anybody" (see http://press-pubs.uchicago.edu/founders/documents/a1_8_8s12.html).The United States Supreme Court stated in this regard: "...the primary purpose of that [patent] law is not to create private fortunes, but is to promote the progress of science and the useful arts”, Motion Picture Patents Co. v. Universal Film Co., 243 United States 502, 1917.

${ }^{27}$ See Article 5A of the Paris Convention for the Protection of Industrial Property. Compulsory licenses were introduced at the Fifth Conference of Revision of the Convention, The Hague, 1925.
} 
developing countries sought to keep it. As disagreement persisted, at the end of the negotiations a compromise was reached and reflected in Article 27.1, in fine, of the TRIPS Agreement: "patents shall be available and patent rights enjoyable without discrimination as to ... whether products are imported or locally produced”.

Some countries interpreted this provision as the death sentence of compulsory licenses for lack or insufficient work. Notably, in January 2001, the United States brought a complaint against Brazil arguing that the Brazilian law's authorization to grant compulsory licenses when patents were not worked was TRIPS-inconsistent. ${ }^{28}$ However, the United States withdrew the complaint before a panel was established, after reaching an agreement with the Brazilian authorities. ${ }^{29}$ The issue has been never raised again before the WTO, despite the fact that other national laws contain provisions allowing for compulsory licenses in cases of lack of working. ${ }^{30}$

Article 27.1 of the TRIPS Agreement does not specify whether the products that are "imported or locally produced" are those of the patent owner or third parties' infringing products. An interpretation of this provision in accordance with the Vienna Convention on the Law of Treaties would indicate that compulsory licenses grounded on the lack or insufficiency of work are TRIPS-compatible (e.g. Correa, 2005a; Mercurio and Tyagi, 2010). The "patent rights" referred to in Article 27.1 are defined in Article 28.1 of the Agreement, which only requires the granting of negative rights with regard to the exploitation of the invention, that is, the right to prevent third parties from using (without authorization) the patented invention. Hence, an interpretation of Article 27.1, read in conjunction with Article 28.1, suggests that the products mentioned in Article 27.1 are infringing products, not the products of the patent owner himself. In other words, Article 27.1 forbids discrimination between infringing imported and infringing locally made products, but it does not prevent the establishment of differential obligations with regard to products made or imported by the patent owner or with his/her consent.

Thus, the non-discrimination clause of Article 27.1 applies in cases where the rights enjoyed by patent owners are different (substantially or procedurally) depending on the foreign or domestic origin of the third parties' products. For instance, Section 337 of the United States Tariff Act was found inconsistent with the GATT in United States -- Section 337 of the Tariff Act of 1930, since it accorded less favourable treatment to imported products challenged as infringing United States patents than that accorded to similarly challenged products of United States origin (Haedicke, 2000).

One example of an effective use of compulsory licenses to promote local production is provided by Canada before the North American Trade Agreement (NAFTA) and the TRIPS Agreement tightened the conditions for the grant of such licenses. Automatic compulsory licenses have been provided for pharmaceutical products since the 1960s (Reichman and Hasenzahl, 2002). The policy was widely successful in promoting the development of a local pharmaceutical industry. When Canada was forced to change the policy, a vibrant domestic pharmaceutical industry had been established. ${ }^{31}$ United States

\footnotetext{
${ }^{28}$ See WTO, Brazil - Measures Affecting Patent Protection, Request for the Establishment of a Panel by the United States, 9 January 2001, document WT/DS199/3.

${ }^{29}$ Without prejudice to their respective positions, the United States and Brazil agreed to enter into bilateral discussions before Brazil makes use of Article 68 against a United States patent holder (see WTO, Brazil Measures Affecting Patent Protection, Notification of Mutually Agreed Solution, documents WT/DS199/4, G/L/454, IP/D/23/Add.1,19 July 2001.

${ }^{30}$ United Kingdom Patents Act 1977, Chapter 37 (as amended by the Copyright, Designs and Patents Act 1988), Section 48(3); Ireland Patents Act 1992, Section 70(2). In some cases, “working” has been defined by national laws as encompassing local production or importation of the patent product (see, e.g. Decision 486 of the Andean Community, Article 60). This obviously dilutes the working obligation.

${ }^{31}$ At the end of 2006, generic medicines accounted in Canada for 45 per cent of all prescriptions and 18 per cent of the \$18-billion market. The Canadian pharmaceutical industry invested 15 per cent of sales in research and development. See http://www.canadiangenerics.ca/en/news/mar_21_07.asp.
} 
has also made a broad use of compulsory licenses. They have generally been granted to remedy anticompetitive practices (particularly in the context of companies' mergers that may lead to a monopolistic market position) or in the exercise of the government's right to use patented inventions (Reichman and Hasenzahl, 2002).

Another option for promoting local production is the use of "refusal to deal" as a ground for the granting of compulsory licenses (Correa, 2007b). Given the freedom that WTO Members have to determine such grounds, "refusal to deal" may be deemed an autonomous ground therefor. ${ }^{32}$ Compulsory licenses for "refusal to deal" are specifically provided for in some national laws (e.g. Argentina, Germany). However, even in the absence of such provisions, those licenses may be based on competition laws. The "essential facilities" doctrine (Correa, 2007b) has been applied in some jurisdictions to deal with situations where access to a technology is essential to undertake production. ${ }^{33}$

A limitation for the use of compulsory licenses as a means of creating space for local production, is the fact that patents' specifications do not normally contain the know-how required for actual production. This may be important in many technological fields, except where the compulsory licensee has sufficient capacity to independently reverse engineer. However, there is nothing preventing countries subject to the TRIPS Agreement from requiring the patent owner to transfer the know-how necessary to execute the patented invention. In fact, some compulsory licenses granted in the United States ordered such a transfer (Correa, 1999).

With the exception of the United States, where compulsory licenses have been granted in a wide range of sectors, those granted after the TRIPS Agreement entered into force have concentrated in the pharmaceutical sector. ${ }^{34}$ Moreover, most of such licenses have been issued in connection with medicines for the treatment of HIV/AIDS (Beall and Kuhn, 2012). In some cases, their aim has been to get access to cheaper imported medicines, while in others the aim was to undertake local production. ${ }^{35}$

It has been argued that the grant of compulsory licenses may discourage further research and development (R\&D) by the companies owning the patents subject to such licenses. However, Scherer (1998) analyzed the extent to which the granting of compulsory licenses affected R\&D expenditures by 70 firms in the United States and found no negative effect on R\&D but, on the contrary, a significant rise in such companies' $R \& D$ relative to companies of comparable size not subject to such licenses. A more recent study compared rates of patenting and other measures of inventive activity before and after six compulsory licenses over drug patents issued in the 1980s and 1990s. It observed "no uniform decline in innovation by companies affected by compulsory licenses" and found "very

\footnotetext{
${ }^{32}$ This is not prevented by the fact that Article 31(b) of the TRIPS Agreement only refers to the refusal of a voluntary license as a pre-condition for granting compulsory licenses, except in the cases where this requirement is waived.

${ }^{33}$ For instance, the Italian Competition Authority (ICA) decided to grant a compulsory license in a case brought before it for an alleged abuse of a dominant position through the refusal by Merck to grant a chemical pharmaceutical manufacturer a license to produce an active ingredient needed for the production of an antibiotic used in the treatment of infectious diseases (Coco and Nebbia, 2007). For other cases, see Correa, 2007.

${ }^{34}$ Compulsory licenses were granted in other sectors in Taiwan Province of China, which issued in 1978 a compulsory license to work a method patent and to produce an agrochemical called "Topsin" patented by Nippon Soda Co. Ltd. In 2004 a compulsory license was granted on patents held by Phillips relating to the manufacture of recordable compact discs ("CD-Rs"). The license was later revoked by a court on the ground that the applicant had failed to provide sufficient and convincing evidence that the terms and conditions proposed to obtain a voluntary license were unreasonable.

${ }^{35}$ For instance, Indian company NATCO Pharmaceuticals obtained a compulsory license on 9 March 2012 to manufacture and sell in India a drug for kidney and liver cancer patented by Bayer. Upon a complaint by Bayer, the Delhi High Court barred NATCO from exporting the product, unless permission for export is given after obtaining the approval of the Drug Controlling Authority. See, e.g. http://www.4-traders.com/BAYER-AG436063/news/Bayer--DELHI-COURT-BARS-NATCOS-GENERIC-CANCER-DRUG-EXPORT-18189305/.
} 
little evidence of a negative impact, which is consistent with earlier empirical work” (Chien, 2003: 1). Another study investigated the effects of compulsory licensing on patenting in Germany resulting from the application of the 1918 United States Trading-with-the-Enemy Act (TWEA) as an empirical setting. The analysis examined data on 79,591 patents for chemicals in Germany between 1900 and 1930. It found a 38 per cent increase in patenting by German inventors after 1918 for fields in which German-owned patents were violated under the TWEA (Baten et al., 2014).

\section{(iii) Parallel imports}

Situations may arise out where IPR-protected products are sold in a particular country at higher prices or under more onerous conditions than in other countries. The principle of exhaustion of rights that WTO members may adopt pursuant to Article 6 of the TRIPS Agreement is another "flexibility" that may be applied to allow for imports of products protected in the importing country without the intervention or consent of the right-holder. ${ }^{36}$

It has been argued that parallel imports may negatively discourage or affect local manufacturing. However, in the absence of the possibility of such imports the patent owner may, in any case, supply the local market through imports. Allowing parallel imports may have direct benefits for consumers (e.g. when medicines can be procured abroad at a lower price than domestically). Such imports may also contribute to reduce the costs of inputs for local production and be functional to industrial policies aiming at promoting local production.

\section{INNOVATION}

The promotion of innovation generally is an important component of industrial policies in countries where the survival or expansion of certain segments of their industries (e.g. electronics, biotechnology, aeronautics, solar panels) hinge upon its capacity to innovate. R\&D intensive sectors are likely to demand broad and strong IPRs protection. However, in countries where technologically mature sectors predominate, factors other than innovation (such as labour and inputs costs) may more decisive in determining output and productivity levels. While, under such circumstances, IPRs may not play a significant role in promoting innovation, they may affect the prices of industrial inputs and, more generally, consumers’ options and expenditures.

IPRs are granted to promote (and reward) innovation and creativity, or to pursue other commercial objectives (such as product differentiation in the case of trademarks and geographical indications). However, their impact strongly depends on the context in which they apply, including the country's production structure, its scientific and technological infrastructure, the availability of risk capital, market size, and other factors. In particular, "an increase in intellectual property rights in a country which is a net importer of technology is likely to benefit overseas rights holders disproportionately compared with domestic rights holders” (Productivity Commission of Australia, 2012: 100).

In fact, the role played by IPRs is promoting innovation is controversial, especially when different levels of development are taken into account. ${ }^{37}$ The evidence on the extent to which patent protection, which is of particular relevance in the context of industrial policies, contributes to encouraging innovation is, at least, inconclusive. Economic studies have shown repeatedly that "patents do not play

\footnotetext{
${ }^{36}$ The TRIPS Agreement leaves open when commercialization in the exporting country has "exhausted" the rights. Some legislation and case law refer to cases where the products were put on the market by the right holder or with his consent, but sales by a compulsory license may also be considered as having exhausted the relevant IPRs, since remuneration must generally be paid by the compulsory licensee.

${ }^{37}$ In an often quoted statement, Machlup (1958: 80) noted in a report to the United States Congress in 1958: "If we did not have a patent system, it would be irresponsible, on the basis of our present knowledge of its economic consequences, to recommend instituting one”.
} 
a particularly important role in most fields of industrial innovation” (Scherer, 2009). Thus, a data survey for the late twentieth century indicated that

[C]ommercial research and development labs in most industries deem alternative mechanisms, such as secrecy and lead-time (being the first firm to offer a new product) to be more effective than patents ... Historical accounts also indicate that innovation often occurs independently of patents as a result of knowledge sharing $\ldots$ or cultural attitudes that encourage risk taking $\ldots$ and scientific experimentation (Moser, 2013: 24).

and that:

[O]verall, the weight of the existing historical evidence suggests that patent policies, which grant strong intellectual property rights to early generations of inventors, may discourage innovation. On the contrary, policies that encourage the diffusion of ideas and modify patent laws to facilitate entry and encourage competition may be an effective mechanism to encourage innovation” (Moser, 2013: 40).

On the basis of a review of economic and historical studies on patent protection, Bessen and Meurer (2008: 80) concluded that "nations with patent systems were not more innovative that nations without patents systems. Similarly, nations with longer patent terms were no more innovative than nations with shorter patent terms".

Although a basic assumption for the grant of patents and other IPRs is a general market failure in the market for innovation, this may not be necessarily the case (Moir, 2009: 33): "in most [industries], the cost of invention is low; or just being first confers a durable competitive advantage ... so there's no point to a patent monopoly that will last 20 years ... Most industries could get along fine without patent protection”.

In fact, much of the significant innovation takes place outside the patent system. ${ }^{38}$ Alternative accounts of United States innovation have emphasized the importance of relative factor prices, and in particular, the high costs of labour relative to the abundance of natural resources, as an impetus for mechanization, and for the development of a specifically American system of manufacturing (Moser, 2013).

\section{A. Industrialization stages and IPRs}

In the light of the above findings and analyses, a careful assessment of industrial capacity is needed in designing IPRs regimes as a component of industrial policies, notably in relation to patent protection. Three stages of industrial development - initiation, internalization and generation - may be identified (see table 2). At the initiation stage, mostly "mature" technologies are incorporated through informal channels of technology transfer (such as the acquisition of machinery and equipment, reverse engineering and subcontracting) as well as through formal modes of transfer (such as turnkey agreements and foreign direct investment). At this stage, the IPRs regime is very unlikely to be relevant in any significant way to promote local innovation; it should ideally allow as much margin as possible for the absorption and diffusion of acquired technologies.

\footnotetext{
${ }^{38}$ A competition organized by the journal Research and Development ("R\&D 100 Awards”), has awarded prizes since 1963 to the 100 most technologically significant new products available for sale or licensing in the year preceding the judgments. An analysis of the patent records showed that only about 10 per cent of "important" inventions were patented (Fontana et al., 2013).
} 
Table 2

Industrialization stages and IPRs

\begin{tabular}{ll}
\hline Initiation stage & Litle or no impact of IP on local innovation. IP may affect access to goods \\
\hline Internalization stage & $\begin{array}{l}\text { Little impact of IP on local innovation. IP may reduce technological diffusion and } \\
\text { affect access to goods }\end{array}$ \\
\hline Generation stage & $\begin{array}{l}\text { IP may help to consolidate local innovation strategies; problems of access remain } \\
\text { for part of the population }\end{array}$ \\
\hline
\end{tabular}

Source: Lee et al. (1988: 242).

The situation of least developed countries, where the focus of technological efforts lies in the mastery of operation and low-level design technology (UNCTAD, 2006: 234), clearly corresponds to the initiation phase. Article 66.1 of the TRIPS Agreement recognized that the implementation of the high standards of IPRs protection contained in the Agreement would be detrimental to LDCs' development. The same logic actually applies to other developing countries where high IPRs protection will most probably not lead to more technology transfer or local innovation.

At the internalization stage, some low-intensity R\&D industries emerge. At this stage, local producers are able to develop "minor" or "incremental" innovations, derived in most cases from the routine exploitation of existing technologies rather than from deliberate R\&D efforts. At this phase, a high level of IP protection may have little or no effect on innovation, while reducing the diffusion and increasing the cost of foreign inputs and technologies. The ideal solution would be to also keep, as in the initiation stage, a flexible IP system, but this possibility is limited by the TRIPS Agreement and, in some cases, by the even higher standards established by free trade agreements (Max Planck Institute, 2012). The design of IPRs legislation should, however, make full use of the flexibilities left to allow reverse engineering and technological diffusion. At both the initiation and internalization stages the main impact of IPRs is likely to be the limitation to the access to protected goods such as medicines.

Finally, at the generation phase, some industries may benefit from IP protection to consolidate their innovation strategies domestically or internationally, as is the case in some advanced developing countries such as Brazil and India. However, there may be a tension between the interests of local innovators and the society at large, since increased levels of protection may reduce technological diffusion and access to the products of innovation.

\section{B. Access to knowledge}

Facilitating access to publicly available knowledge and the possibility of using patented technologies to undertake research or experimentation may be important elements in an industrial policy aiming at promoting local innovation and production.

Avoiding barriers to the access to technical knowledge that can be used as a source of innovation may expand the room for local innovation activities. In particular, local firms should be able to get access to information available in the web without undue restrictions. Copyright regimes, hence, should not include anti-circumvention measures ${ }^{39}$ (which are not mandated by the TRIPS Agreement) that may unduly prevent or encumber free access to such information.

\footnotetext{
39 These are measures introduced in some national laws and provided for the in the WIPO Copyright Treaty of 1996, which prohibit the circumvention of technological barriers adopted to prevent the use of digital materials.
} 
Another measure, allowed by the TRIPS Agreement under the general rule contained in its Article 30, is a research or experimentation exception. This exception may permit (depending on its formulation in the national law) any party to undertake research on or experimenting with a patented invention for commercial or non-commercial purposes, including testing the validity of a patent, improving on an invention or determining the interest in applying for a voluntary or compulsory license. The right to undertake these activities on a patent subject matter, is consistent with the conception of patent protection as a "means to induce inventors to disclose their invention to the public in order to facilitate the dissemination and advancement of technical knowledge"; under this conception, "it appears illegitimate to prevent experimental use during the term of the patent” (Senftleben, 2004: 229).

A broad research exception may foster "inventing around" patented inventions and the development of follow-on innovations. In the case of pharmaceuticals, an exception of this type may allow local firms to initiate production as soon as a patent expires, if they are allowed to undertake the tests necessary to obtain the marketing approval of a pharmaceutical product before the expiry of the relevant patent. ${ }^{40}$

In order to ensure a sufficient freedom to experiment or carry out research on a patented invention, ${ }^{41}$ the exception should desirably meet the following requirements. ${ }^{42}$ The exception should:

- be applicable to acts conducted for scientific or technological purposes.

- $\quad$ apply to any party, including commercial entities, and not only when experimentation or research is done privately or in an academic environment; ${ }^{43}$

- $\quad$ cover acts done with or without gainful intent;

- allow for any acts done for experimental purposes, including production, importation and use of samples of the patented product or implementation of the patented process for testing and research.

While in order to facilitate local innovation national laws should contemplate well drafted research or experimentation exceptions, the main tool to preserve freedom to operate by local firms will, in any case, be the implementation of rigorous policies regarding the scope of patentability, as discussed above. Such exceptions may provide a defence in case an infringement is alleged. If, in using the flexibility to determine the concept of invention and the standards of patentability, patents on particular technologies are not granted, local firms would not be exposed to costly litigation and the risk of being excluded from the market through provisional or permanent injunctions.

\footnotetext{
${ }^{40}$ This is generally known as the "Bolar" or "early working" exception. The consistency of this exception with the TRIPS Agreement was confirmed by a WTO panel in Canada-Patent protection of pharmaceutical products (WT/DS114/R, 17 March 2000).

${ }^{41}$ The United States courts provided in Madey v. Duke University (307 F.3d 1351; Fed. Cir. 2002) a very narrow interpretation of the experimentation exception under United States law, but this interpretation needs not to be extrapolated to other jurisdictions.

${ }^{42}$ For an analysis of comparative law on the subject see Correa (2005b).

${ }^{43}$ Many patent laws refer, however, to scientific research only (e.g., patent law of Algeria [article 12(1)], Barbados [article 6(1)], Cuba [article 54(3)], Egypt [article 101(1) (1)], Guinea-Bissau [article 4(c)], Kenya [article 58(1)], Lebanon (article 42) Malaysia [article 37(1)], Saudi Arabia (article 24) and Uganda [article 29(a)].
} 


\section{CONCLUSIONS}

While today developed countries were able to design their IPRs regimes in accordance with their evolving industrial and technological capabilities, the TRIPS Agreement has constrained the freedom of developing countries to follow the same approach. The IPRs protections mandated by that Agreement may, in particular, affect the implementation of industrial policies aimed at fostering local production.

Whether IPRs can generate a net benefit or cost to a particular country is dependent on its productive profile, $R \& D$ infrastructure and other factors, and on the extent to which policy space is preserved to adapt the IPRs regime to local conditions and needs.

Applying rigorous standards of patentability may be one of the most important tools to preserve a sufficient freedom to operate under patent regimes, thereby allowing for the imitation of technologies and local production. This is particularly critical in sectors where "evergreening" strategies are common, such as in pharmaceuticals.

Compulsory licenses may, where voluntary licenses are not available on reasonable commercial terms, be used as an instrument to open space for local production. They have been used so far in a limited way in developing countries and in relation to medicines only. Such licenses may be more broadly used to allow for local production of protected products, provided that the know-how required for production (generally not disclosed in patent documents) can be obtained from the patent owner or through reverse engineering.

The role of IPRs, particularly patents, in promoting innovation is controversial. A number of economic studies in developed countries call in question the conventional thinking about patents as a driver of innovation. Patents are unlikely to foster innovation in developing countries at early stages of industrialization. While research or experimentation exceptions can be provided for, consistently with the TRIPS Agreement, including when undertaken with commercial intent, the main policy that can be applied is to rigorously define the patentability standards and thereby avoid the grant of unwarranted patent rights that may be used to block local innovation and production. 


\section{REFERENCES}

Baten J, Bianchi N and Moser P (2014). Patents, competition, and innovation - evidence from compulsory licensing during WWI. Working Paper No. 526, Center for International Development, Stanford, CA.

Beall R and Kuhn R (2012). Trends in compulsory licensing of pharmaceuticals since the Doha Declaration: A database analysis. PLoS Medicine, 9(1): e1001154. Available at: http:/www.plosmedicine.org/ article/fetchObject.action?uri=info:doi/10.1371/journal.pmed.1001154\&representation=PDF.

Bessen J and Meurer MJ (2008). Patent Failure: How Judges, Bureaucrats, and Lawyers Put Innovators at Risk. Princeton and Oxford, Princeton University Press.

Chien C (2003). Cheap drugs at what price to innovation: Does the compulsory licensing of pharmaceuticals hurt innovation? Berkeley Technology Law Journal, 18(3): 853-907.

Coco R and Nebbia P (2007). Compulsory licensing and interim measures in Merck: A case for Italy or for antitrust law? Journal of Intellectual Property Law \& Practice, 2(7): 452-462.

Commission on Intellectual Property Rights (2002). Integrating Intellectual Property Rights and development policy. London. Available at: http://www.iprcommission.org/papers/pdfs/final_report/CIPRfullfinal.pdf.

Correa CM (1999). Intellectual property rights and the use of compulsory licenses: Options for developing countries. T.R.A.D.E. Working Paper No. 5, South Centre, Geneva.

Correa CM (2000). Medidas cautelares en materia de patentes de invención. Jurisprudencia Argentina, Número Especial, 20 November, Buenos Aires.

Correa CM (2005a). Can the TRIPS Agreement foster technology transfer to developing countries? In: Maskus KE and Reichman JH, eds. International Public Goods and Transfer of Technology under a Globalized Intellectual Property Regime. Cambridge, Cambridge University Press: 227-256.

Correa CM (2005b). The international dimension of the research exception. Washington, DC. Project on Science and Intellectual Property in the Public Interest (SIPPI), the American Association for the Advancement of Science.

Correa CM (2007a). Trade Related Aspects of Intellectual Property Rights: A Commentary on the TRIPS Agreement (Oxford Commentaries on the GATT/WTO Agreements). Oxford, Oxford University Press.

Correa CM (2007b). Intellectual property and competition law: Exploring some issues of relevance to developing countries. Issue Paper No. 21, International Centre for Trade and Sustainable Development (ICTSD), Geneva.

Correa CM (2010). Designing Intellectual Property Policies in Developing Countries. Penang, Third World Network.

Correa CM (2011). Pharmaceutical innovation, incremental patenting and compulsory licensing. Research Paper No. 41, South Centre, Geneva.

Correa CM (2013). Investment agreements: A new threat to the TRIPS flexibilities? South Bulletin, 72: $23-25$.

Executive Office of the President of the United States (2013). Administration strategy on mitigating the theft of U.S. trade secrets. The White House, Washington, DC. Available at: https://www.whitehouse.gov/ sites/default/files/omb/IPEC/admin_strategy_on_mitigating_the_theft_of_u.s._trade_secrets.pdf.

Federal Trade Commission (2003). To promote innovation: The proper balance of competition and patent law and policy. A report by the Federal Trade Commission. Washington, DC. Available at: http://www.ftc.gov/os/2003/10/innovationrpt.pdf.

Fontana R, Nuvolari A, Shimizu H and Vezzulli A (2013). Reassessing patent propensity: Evidence from a dataset of R\&D awards 1977-2004. Research Policy, 42(10): 1780-1792.

Gerster R (2001). Patents and Development: Lessons Learnt from the Economic History of Switzerland. Intellectual Property Rights Series No.4, Penang, Third World Network.

Girouard RJ (1996). US trade policy and the Japanese patent system. BRIE Working Paper No. 89, Berkeley Roundtable on the International Economy, Berkeley.

Haedicke M (2000). U.S. imports, TRIPS and section 337 of the Tariff Act of 1930. International Review of Industrial Property and Copyright Law, 31(7-8): 771-782.

Halewood M (1997) Regulating patent holders: Local working requirements and compulsory licences at international law. Osgoode Hall Law Journal, 35(2): 243-287.

Hoeren T (2010). The protection of semiconductor chip products in TRIPS. In: Correa CM ed. Research Handbook on the Protection of Intellectual Property under WTO Rules: Intellectual Property in the WTO, Volume I. Cheltenham and Northampton, Edward Elgar Publishing: 698-712. 
Jaffe AB and Lerner J (2004). Innovation and Its Discontents: How Our Broken Patent System is Endangering Innovation and Progress, and What to Do About It. Princeton, Princeton University Press.

Khor M (2012). Climate change, technology and intellectual property rights: Context and recent negotiations. Research Paper No. 45, South Centre, Geneva.

Lee J, Bae ZT and Choi DK (1988). Technology development processes: A model for a developing country with a global perspective. $R \& D$ Management, 18(3): 235-250.

Machlup F (1958). An economic review of the patent system. Study of the Subcommittee on Patents, Trademarks, and Copyrights of the Committee on the Judiciary, United States Senate, Study No. 15, United States Government Printing Office, Washington, DC.

Max Planck Institute (2012). Principles for intellectual property provisions in bilateral and regional trade agreements. Available at: http://www.ip.mpg.de/files/pdf2/Principles_for_IP_provisions_in_Bilateral_and_Regional_ Agreements_final1.pdf.

Mercurio B and Tyagi M (2010). Treaty interpretation in WTO Dispute Settlement: The outstanding question of the legality of local working requirements. Minnesota Journal of International Law, 19(2): 275-326.

Moir HVJ (2009). What are the costs and benefits of patent systems? In: Arup C and Van Caenegem W, eds. Intellectual Property Policy Reform: Fostering Innovation and Development. Cheltenham and Northampton, Edward Elgar Publishing.

Moser P (2013). Patents and innovation: Evidence from economic history. Journal of Economic Perspectives, 27(1): 23-44.

Musungu S and Oh C (2005). The use of flexibilities in TRIPS by developing countries: Can they promote access to medicines? Commission on Intellectual Property Rights, Innovation and Public Health, Geneva. Available at: http://www.who.int/intellectualproperty/studies/TRIPSFLEXI.pdf.

Ordover JA (1991). A patent system for both diffusion and exclusion. Journal of Economic Perspectives, 5(1): 43-60.

Productivity Commission of Australia (2012). Trade \& Assistance Review 2010-11. Annual Report Series, Canberra.

Reichman JH (1996-1997). From free riders to fair followers: Global competition under the TRIPS Agreement. New York University Journal of International Law and Politics, 29(1-2): 11-94.

Reichman JH and Hasenzahl C (2002). Non-voluntary licensing of patented inventions: Historical perspective, legal framework under TRIPS and an overview of the practice in Canada and the USA. Issues Paper No. 5, UNCTAD and International Centre for Trade and Sustainable Development (ICTSD), Geneva.

Ritter DS (2004). Switzerland's patent law history. Fordham Intellectual Property, Media and Entertainment Law Journal, 14(2): 463-496.

Rochmyaningsih D (2013). Indonesia excels in patents from local scientists. SciDevNet. Available at: http://www. scidev.net/asia-pacific/innovation/news/indonesia-excels-in-patents-from-local-scientists.html.

Scherer FM (1998) Comment. In: Anderson R and Gallini NT, eds. Competition Policy and Intellectual Property Rights in the Knowledge-based Economy. Alberta, University of Calgary Press.

Scherer FM (2009). The political economy of patent policy reform on the United States. Journal on Telecommunications and High Technology Law, 7(2): 167-216.

Senftleben M (2004 ). Copyright, Limitations and the Three-Step Test. An Analysis of the Three-Step Test in International and EC Copyright Law. The Hague, Kluwer Law International.

Suthersanen U, Dutfield G and Chow KB eds. (2007). Innovation without Patents. Harnessing the Creative Spirit in a Diverse World. Cheltenham and Northampton, Edward Elgar Publishing.

Tamura Y (2013). IP-based nation: Strategy of Japan. In: Abbott FM, Correa CM and Drahos P eds. Emerging Markets and the World Patent Order. Cheltenham and Northampton, Edward Elgar Publishing.

United States Congress, Office of Technology Assessment (1986). Intellectual Property Rights in an Age of Electronics and Information. Document OTA-CIT-302, United States Government Printing Office, Washington, DC.

UNAIDS, WHO and UNDP (2011). Using TRIPS flexibilities to improve access to HIV treatment. Policy Brief. Joint United Nations Programme on HIV/AIDS, World Health Organization and United Nations Development Programme. Available at: http://www.unaids.org/sites/default/files/en/media/unaids/contentassets/documents/ unaidspublication/2011/JC2049_PolicyBrief_TRIPS_en.pdf.

UNCTAD (2006). The Least Developed Countries Report 2006: Developing Productive Capacities. United Nations publication, sales no. E.06.11.D.9. New York and Geneva. 
UNEP and EPO (2013). Patents and Clean Energy Technologies in Africa. United Nations Environment Programme and European Patent Office, Nairobi and Munich.

UNEP, EPO and ICTSD (2010). Patents and clean energy: Bridging the gap between evidence and policy-making. United Nations Environment Programme, European Patent Office and International Centre for Trade and Sustainable Development, Nairobi, Munich and Geneva. Available at: http://www.unep.ch/etb/events /UNEP\%20EPO\%20ICTSD\%20Event\%2030\%20Sept\%202010\%20Brussels/Study\%20Patents\%20and\%20cle an\%20energy_15.9.10.pdf.

Vaidhyanathan S (2001). Copyrights and Copywrongs: The Rise of Intellectual Property and How It Threatens Creativity. New York, New York University Press.

Zeitsch J (2013). The economic value of the Australian innovation patent: The Australian innovation patent survey. Verve Economics, Canberra. Available at: http:/www.acip.gov.au/pdfs/Economic_Value_of_ the_Innovation_Patent_-_Final_Report_-_Verve_Economics_-_24_Mar_2013.pdf.

World Bank (2001). Global Economic Prospects and the Developing Countries 2002. Washington, DC.

WHO (2006). Public health, innovation and intellectual property rights: Report of the Commission on Intellectual Property Rights, Innovation and Public Health. World Health Organization, Geneva. Available at: http://www.who.int/ intellectualproperty/documents/thereport/ENPublicHealthReport.pdf?ua=1.

WIPO (2011). Patent landscape report on Ritonavir. World Intellectual Property Organization, Geneva. Available at: http://www.wipo.int/edocs/pubdocs/en/patents/946/wipo_pub_946.pdf. 
UNCTAD Discussion PAPERs

\begin{tabular}{|c|c|c|c|}
\hline No. & Date & Author(s) & Title \\
\hline 222 & July 2015 & Ulrich Hoffmann & $\begin{array}{l}\text { Can green growth really work and what are the true } \\
\text { (socio-) economics of climate change? }\end{array}$ \\
\hline 221 & May 2015 & Eric Helleiner & $\begin{array}{l}\text { International policy coordination for development: The } \\
\text { forgotten legacy of Bretton Woods }\end{array}$ \\
\hline 220 & May 2015 & $\begin{array}{l}\text { Martin Falk and } \\
\text { Eva Hagsten }\end{array}$ & E-commerce trends and impacts across Europe \\
\hline 219 & March 2015 & $\begin{array}{l}\text { Piergiuseppe Fortunato, } \\
\text { Carlos Razo and } \\
\text { Kasper Vrolijk }\end{array}$ & $\begin{array}{l}\text { Operationalizing the product space: A road map to export } \\
\text { diversification }\end{array}$ \\
\hline 218 & December 2014 & Daniel Poon & $\begin{array}{l}\text { China's development trajectory: A strategic opening for } \\
\text { industrial policy in the South }\end{array}$ \\
\hline 217 & November 2014 & Y1lmaz Akyüz & $\begin{array}{l}\text { Internationalization of finance and changing } \\
\text { vulnerabilities in emerging and developing economies }\end{array}$ \\
\hline 216 & April 2014 & Andrew Cornford & $\begin{array}{l}\text { Macroprudential regulation: Potential implications for } \\
\text { rules for cross-border banking }\end{array}$ \\
\hline 215 & March 2014 & Stephany Griffith-Jones & A BRICS development bank: A dream coming true? \\
\hline 214 & December 2013 & Jörg Mayer & $\begin{array}{l}\text { Towards more balanced growth strategies in developing } \\
\text { countries: Issues related to market size, trade balances } \\
\text { and purchasing power }\end{array}$ \\
\hline 213 & November 2013 & Shigehisa Kasahara & $\begin{array}{l}\text { The Asian developmental State and the Flying Geese } \\
\text { paradigm }\end{array}$ \\
\hline 212 & November 2013 & $\begin{array}{l}\text { Vladimir Filimonov, } \\
\text { David Bicchetti, } \\
\text { Nicolas Maystre and } \\
\text { Didier Sornette }\end{array}$ & $\begin{array}{l}\text { Quantification of the high level of endogeneity and of } \\
\text { structural regime shifts in commodity markets }\end{array}$ \\
\hline 211 & October 2013 & $\begin{array}{l}\text { André Nassif, } \\
\text { Carmem Feijó and } \\
\text { Eliane Araújo }\end{array}$ & $\begin{array}{l}\text { Structural change and economic development: Is Brazil } \\
\text { catching up or falling behind? }\end{array}$ \\
\hline 210 & December 2012 & $\begin{array}{l}\text { Giovanni Andrea Cornia } \\
\text { and Bruno Martorano }\end{array}$ & $\begin{array}{l}\text { Development policies and income inequality in selected } \\
\text { developing regions, } 1980-2010\end{array}$ \\
\hline 209 & November 2012 & $\begin{array}{l}\text { Alessandro Missale and } \\
\text { Emanuele Bacchiocchi }\end{array}$ & Multilateral indexed loans and debt sustainability \\
\hline 208 & October 2012 & $\begin{array}{l}\text { David Bicchetti and } \\
\text { Nicolas Maystre }\end{array}$ & $\begin{array}{l}\text { The synchronized and long-lasting structural change on } \\
\text { commodity markets: Evidence from high frequency data }\end{array}$ \\
\hline 207 & July 2012 & $\begin{array}{l}\text { Amelia U. Santos- } \\
\text { Paulino }\end{array}$ & $\begin{array}{l}\text { Trade, income distribution and poverty in developing } \\
\text { countries: A survey }\end{array}$ \\
\hline 206 & December 2011 & $\begin{array}{l}\text { André Nassif, } \\
\text { Carmem Feijó } \\
\text { and Eliane Araújo }\end{array}$ & $\begin{array}{l}\text { The long-term "optimal" real exchange rate and } \\
\text { the currency overvaluation trend in open emerging } \\
\text { economies: The case of Brazil }\end{array}$ \\
\hline 205 & December 2011 & Ulrich Hoffmann & $\begin{array}{l}\text { Some reflections on climate change, green growth } \\
\text { illusions and development space }\end{array}$ \\
\hline 204 & October 2011 & Peter Bofinger & The scope for foreign exchange market interventions \\
\hline 203 & September 2011 & $\begin{array}{l}\text { Javier Lindenboim, } \\
\text { Damián Kennedy and } \\
\text { Juan M. Graña }\end{array}$ & $\begin{array}{l}\text { Share of labour compensation and aggregate demand } \\
\text { discussions towards a growth strategy }\end{array}$ \\
\hline 202 & June 2011 & Pilar Fajarnes & $\begin{array}{l}\text { An overview of major sources of data and analyses } \\
\text { relating to physical fundamentals in international } \\
\text { commodity markets }\end{array}$ \\
\hline
\end{tabular}




\begin{tabular}{|c|c|c|c|}
\hline No. & Date & Author(s) & Title \\
\hline 201 & February 2011 & Ulrich Hoffmann & $\begin{array}{l}\text { Assuring food security in developing countries under the } \\
\text { challenges of climate change: Key trade and development } \\
\text { issues of a fundamental transformation of agriculture }\end{array}$ \\
\hline 200 & September 2010 & Jörg Mayer & Global rebalancing: Effects on trade flows and employment \\
\hline 199 & June 2010 & $\begin{array}{l}\text { Ugo Panizza, } \\
\text { Federico Sturzenegger } \\
\text { and Jeromin Zettelmeyer }\end{array}$ & International government debt \\
\hline 198 & April 2010 & $\begin{array}{l}\text { Lee C. Buchheit and } \\
\text { G. Mitu Gulati }\end{array}$ & Responsible sovereign lending and borrowing \\
\hline 197 & March 2010 & Christopher L. Gilbert & $\begin{array}{l}\text { Speculative influences on commodity futures prices } \\
\text { 2006-2008 }\end{array}$ \\
\hline 196 & November 2009 & Michael Herrmann & $\begin{array}{l}\text { Food security and agricultural development in times of } \\
\text { high commodity prices }\end{array}$ \\
\hline 195 & October 2009 & Jörg Mayer & $\begin{array}{l}\text { The growing interdependence between financial and } \\
\text { commodity markets }\end{array}$ \\
\hline 194 & June 2009 & Andrew Cornford & $\begin{array}{l}\text { Statistics for international trade in banking services: } \\
\text { Requirements, availability and prospects }\end{array}$ \\
\hline 193 & January 2009 & Sebastian Dullien & $\begin{array}{l}\text { Central banking, financial institutions and credit creation } \\
\text { in developing countries }\end{array}$ \\
\hline 192 & November 2008 & Enrique Cosio-Pascal & $\begin{array}{l}\text { The emerging of a multilateral forum for debt } \\
\text { restructuring: The Paris Club }\end{array}$ \\
\hline 191 & October 2008 & Jörg Mayer & Policy space: What, for what, and where? \\
\hline 190 & October 2008 & Martin Knoll & $\begin{array}{l}\text { Budget support: A reformed approach or old wine in new } \\
\text { skins? }\end{array}$ \\
\hline 189 & September 2008 & Martina Metzger & Regional cooperation and integration in sub-Saharan Africa \\
\hline 188 & March 2008 & Ugo Panizza & $\begin{array}{l}\text { Domestic and external public debt in developing } \\
\text { countries }\end{array}$ \\
\hline 187 & February 2008 & Michael Geiger & $\begin{array}{l}\text { Instruments of monetary policy in China and their } \\
\text { effectiveness: 1994-2006 }\end{array}$ \\
\hline 186 & January 2008 & Marwan Elkhoury & $\begin{array}{l}\text { Credit rating agencies and their potential impact on } \\
\text { developing countries }\end{array}$ \\
\hline 185 & July 2007 & Robert Howse & The concept of odious debt in public international law \\
\hline 184 & May 2007 & André Nassif & $\begin{array}{l}\text { National innovation system and macroeconomic policies: } \\
\text { Brazil and India in comparative perspective }\end{array}$ \\
\hline 183 & April 2007 & Irfan ul Haque & Rethinking industrial policy \\
\hline 182 & October 2006 & Robert Rowthorn & $\begin{array}{l}\text { The renaissance of China and India: implications for the } \\
\text { advanced economies }\end{array}$ \\
\hline 181 & October 2005 & Michael Sakbani & $\begin{array}{l}\text { A re-examination of the architecture of the international } \\
\text { economic system in a global setting: Issues and proposals }\end{array}$ \\
\hline 180 & October 2005 & $\begin{array}{l}\text { Jörg Mayer and } \\
\text { Pilar Fajarnes }\end{array}$ & Tripling Africa's Primary Exports: What? How? Where? \\
\hline 179 & April 2005 & S.M. Shafaeddin & $\begin{array}{l}\text { Trade liberalization and economic reform in developing } \\
\text { countries: structural change or de-industrialization? }\end{array}$ \\
\hline 178 & April 2005 & Andrew Cornford & Basel II: The revised framework of June 2004 \\
\hline 177 & April 2005 & Benu Schneider & $\begin{array}{l}\text { Do global standards and codes prevent financial crises? } \\
\text { Some proposals on modifying the standards-based approach }\end{array}$ \\
\hline 176 & December 2004 & Jörg Mayer & $\begin{array}{l}\text { Not totally naked: Textiles and clothing trade in a quota } \\
\text { free environment }\end{array}$ \\
\hline 175 & August 2004 & S.M. Shafaeddin & $\begin{array}{l}\text { Who is the master? Who is the servant? Market or } \\
\text { Government? }\end{array}$ \\
\hline
\end{tabular}




\begin{tabular}{|c|c|c|c|}
\hline No. & Date & Author(s) & Title \\
\hline 174 & August 2004 & Jörg Mayer & $\begin{array}{l}\text { Industrialization in developing countries: Some evidence } \\
\text { from a new economic geography perspective }\end{array}$ \\
\hline 173 & June 2004 & Irfan ul Haque & Globalization, neoliberalism and labour \\
\hline 172 & June 2004 & Andrew J. Cornford & $\begin{array}{l}\text { The WTO negotiations on financial services: Current } \\
\text { issues and future directions }\end{array}$ \\
\hline 171 & May 2004 & Andrew J. Cornford & Variable geometry for the WTO: Concepts and precedents \\
\hline 170 & May 2004 & $\begin{array}{l}\text { Robert Rowthorn and } \\
\text { Ken Coutts }\end{array}$ & $\begin{array}{l}\text { De-industrialization and the balance of payments in } \\
\text { advanced economies }\end{array}$ \\
\hline 169 & April 2004 & Shigehisa Kasahara & $\begin{array}{l}\text { The flying geese paradigm: A critical study of its } \\
\text { application to East Asian regional development }\end{array}$ \\
\hline 168 & February 2004 & Alberto Gabriele & $\begin{array}{l}\text { Policy alternatives in reforming power utilities in } \\
\text { developing countries: A critical survey }\end{array}$ \\
\hline 167 & January 2004 & $\begin{array}{l}\text { Richard Kozul-Wright } \\
\text { and Paul Rayment }\end{array}$ & Globalization reloaded: An UNCTAD Perspective \\
\hline 166 & February 2003 & Jörg Mayer & The fallacy of composition: A review of the literature \\
\hline 165 & November 2002 & Yuefen Li & China's accession to WTO: Exaggerated fears? \\
\hline 164 & November 2002 & $\begin{array}{l}\text { Lucas Assuncao and } \\
\text { ZhongXiang Zhang }\end{array}$ & Domestic climate change policies and the WTO \\
\hline 163 & November 2002 & A.S. Bhalla and S. Qiu & $\begin{array}{l}\text { China's WTO accession. Its impact on Chinese } \\
\text { employment }\end{array}$ \\
\hline 162 & July 2002 & $\begin{array}{l}\text { Peter Nolan and } \\
\text { Jin Zhang }\end{array}$ & The challenge of globalization for large Chinese firms \\
\hline 161 & June 2002 & $\begin{array}{l}\text { Zheng Zhihai and } \\
\text { Zhao Yumin }\end{array}$ & China's terms of trade in manufactures, 1993-2000 \\
\hline 160 & June 2002 & S.M. Shafaeddin & $\begin{array}{l}\text { The impact of China's accession to WTO on exports of } \\
\text { developing countries }\end{array}$ \\
\hline 159 & May 2002 & $\begin{array}{l}\text { Jörg Mayer, } \\
\text { Arunas Butkevicius and } \\
\text { Ali Kadri }\end{array}$ & Dynamic products in world exports \\
\hline 158 & April 2002 & $\begin{array}{l}\text { Yilmaz Akyüz and } \\
\text { Korkut Boratav }\end{array}$ & The making of the Turkish financial crisis \\
\hline 157 & September 2001 & Heiner Flassbeck & The exchange rate: Economic policy tool or market price? \\
\hline 156 & August 2001 & Andrew J. Cornford & $\begin{array}{l}\text { The Basel Committee's proposals for revised capital } \\
\text { standards: Mark } 2 \text { and the state of play }\end{array}$ \\
\hline 155 & August 2001 & Alberto Gabriele & $\begin{array}{l}\text { Science and technology policies, industrial reform and } \\
\text { technical progress in China: Can socialist property rights } \\
\text { be compatible with technological catching up? }\end{array}$ \\
\hline 154 & June 2001 & Jörg Mayer & $\begin{array}{l}\text { Technology diffusion, human capital and economic } \\
\text { growth in developing countries }\end{array}$ \\
\hline 153 & December 2000 & Mehdi Shafaeddin & $\begin{array}{l}\text { Free trade or fair trade? Fallacies surrounding the theories } \\
\text { of trade liberalization and protection and contradictions in } \\
\text { international trade rules }\end{array}$ \\
\hline 152 & December 2000 & Dilip K. Das & Asian crisis: Distilling critical lessons \\
\hline 151 & October 2000 & Bernard Shull & $\begin{array}{l}\text { Financial modernization legislation in the United States - } \\
\text { Background and implications }\end{array}$ \\
\hline 150 & August 2000 & Jörg Mayer & $\begin{array}{l}\text { Globalization, technology transfer and skill accumulation } \\
\text { in low-income countries }\end{array}$ \\
\hline
\end{tabular}

UNCTAD Discussion Papers are available on the UNCTAD website at http://unctad.org. 
